\title{
Gestational Changes in Renal Responsiveness to Cortisol in the Ovine Fetus
}

\author{
MICHELlE K. TOWSTOLESS, JOHN G. MCDOUGALL, AND E. MARELYN WINTOUR \\ Department of Physiology and the Howard Florey Institute of Experimental Physiology and Medicine, University \\ of Melbourne, Parkville [J.G.M., E.M.W.]; and Department of Chemistry and Biology, Footscray Institute of
}

Technology, Footscray, Victoria [M.K.T.], Australia

\begin{abstract}
The ontogenetic renal responsiveness to exogenous cortisol was examined in the chronically cannulated ovine fetus. The contribution of effects at proximal and distal tubule of the kidney were studied also. Cortisol $(81.5 \mu \mathrm{g} / \mathrm{h})$ was infused into immature ovine fetuses (mean gestational age -113.9 days) on five occasions and increased blood cortisol from $0.8 \pm 0.5$ to $21.3 \pm 6.2 \mathrm{nmol} /$ liter. This dose of cortisol produced a highly significant diuresis and natriuresis, in part due to an increase in GFR and in part due to a significant decrease in proximal tubular reabsorption of sodium. Cortisol $(107.2 \pm 4.7 \mu \mathrm{g} / \mathrm{h})$ was infused into mature fetuses (mean gestational age 133.4 days) and produced an increase in blood cortisol concentration from $11.4 \pm 5.6$ to $33.7 \pm 6.8 \mathrm{nmol} / \mathrm{liter}$. No natriuresis or diuresis was seen in the mature fetuses. Cortisol caused a significant depression of proximal tubular sodium reabsorption in mature fetuses, but this extra load was reabsorbed in the distal tubule in these fetuses. The inability of the premature or very low birth wt baby to maintain normal sodium balance on a standard salt intake may be due, at least in part, to a "fetal" renal response to the high plasma cortisol concentrations found in such babies. As the kidney matures it becomes capable of increasing distal tubular sodium reabsorption to compensate for any increased distal tubular fluid delivery. (Pediatr Res 26: 610, 1989)
\end{abstract}

\section{Abbreviations}

$F_{\mathrm{Na}}$, fractional reabsorption of sodium $\mathbf{F R}_{\mathbf{1}, \text {, fractional reabsorption of lithium }}$

$\mathrm{U}_{\mathrm{Na}} \mathrm{V}, \mathrm{U}_{\mathrm{K}} \mathrm{V}, \mathrm{U}_{\mathrm{Cl}} \mathrm{V}, \mathrm{U}_{\mathrm{Ca}} \mathrm{V}$, renal excretion rate of sodium/ potassium/chloride/calcium

Both premature and low birth wt neonates have been reported to exhibit excessive renal salt loss $(1-3)$, the magnitude of which is inversely proportional to the gestational age of the fetus at delivery (1). These neonates frequently develop hyponatremia, which is not confined to the immediate days after birth, but may also occur sporadically for 2 to $6 \mathrm{wk}$ (3).

Sulyok et al. (4) correlated excessive renal salt loss in premature and low birth wt neonates with increases in plasma aldosterone concentration, suggesting that renal insensitivity to aldosterone

Received November 21, 1988; accepted March 15, 1989.

Correspondence Dr. E. M. Wintour. Department of Physiology, University of Mclbourne, Parkville, 3052, Victoria, Australia.

Supported by grants from the National Health and Medical Research Council of Australia to the Howard Florey Institute of Experimental Physiology and Medicine. M.K.T. was supported by a scholarship from the Sudden Infant Death Research Foundation of Australia. may be responsible for neonatal hyponatremia. However, subsequent investigations have shown that a characteristic of this defect is decreased proximal tubule reabsorption of sodium (2) implying that renal insensitivity to aldosterone may be only partially responsible.

The relative immaturity of renal function in very low birth wt and premature neonates seems to be important in the pathogenesis of hyponatremia. Premature neonates exhibit a greater natriuresis and a lower GFR in response to oral salt loading when compared to full-term neonates $(5,6)$. This is consistent with histopathologic studies that show that glomerular formation in the human infant is not complete until late in gestation (7), whereas tubular development is not complete until 1 y after birth (8).

In mature mammals the presence of adrenal steroids is essential for normal renal function. A characteristic of adrenalectomized or hypophysectomized animals and patients with adrenal or pituitary insufficiency is a delayed diuresis following oral or parenteral water loading, accompanied by impaired sodium conservation and reduced GFR and renal blood flow. Administration of deoxycortisone acetate or aldosterone in the presence of normal sodium balance and extra-cellular volume has no effect on the delayed diuresis, whereas cortisol-like steroids correct this diuresis (9-11).

Clinical investigations have reported that premature neonates have higher plasma cortisol concentrations (12) especially when suffering respiratory distress (13). Wintour et al. (14), demonstrated that cortisol was both natriuretic and diuretic in the premature ovine fetus. They hypothesized that the kidneys of premature or low birth wt neonates may be functionally more closely related to those of the fetus rather than a full-term neonate and suggested that the inability of premature or low birth wt babies to retain sodium adequately on a standard salt intake may be due, in part, to the effect of cortisol on the immature kidney.

The aims of the present investigation were 2-fold. First, to investigate ontogenetic renal responsiveness to cortisol in the chronically cannulated ovine fetus and second, to examine the possible mechanism(s) by which cortisol, at physiologic doses, produces both natriuresis and diuresis in immature ovine fetuses.

\section{MATERIALS AND METHODS}

Animals. The chronically cannulated fetuses of cross-bred Merino ewes of known mating dates were used for the present investigation. The procedure for fetal cannulation and the maintenance of cannulas has been described previously (15). Briefly, silastic cannulae $(0.76 \mathrm{~mm}$ inner diameter and $1.65 \mathrm{~mm}$ outer diameter) were inserted into one carotid artery, one jugular vein, and transabdominally into the bladder of fetuses between 98 and 117 days of gestation (term $=147 \pm 5$ days) at which time a catheter was also inserted into the right jugular vein of the pregnant ewe. The ewes were allowed to recover for 7 days after 
surgery, while being maintained in individual metabolic cages with food and water ad libitum. All ewes received a $3 \mathrm{~g} \mathrm{NaCl}$ supplement daily to ensure that the ewe was sodium replete. As aldosterone can cross the ovine placenta, we wished to ensure that no maternal aldosterone was acting on the fetal kidney. On the day of the experiment, drinking water was removed from the cage. Fetuses were categorized as mature ( $>120$ days, $n=5)$ or immature ( $<120$ days, $n=5)$ according to their gestational age on the day of experimentation. Experiments were not performed when the fetus was thought to be stressed, i.e., when fetal urine osmolality, arterial blood gases, and hematocrit were outside the normal range (16). All fetuses received both cortisol and saline infusions, in random order, at least 2 days apart.

Experimental protocol. On the day of the experiment fetal urine was drained for at least $30 \mathrm{~min}$ to ensure an empty bladder. Hourly urine collections were then made for a subsequent $8 \mathrm{~h}$ for the measurement of $\mathrm{pH}$, osmolality, electrolyte concentrations, ${ }^{51} \mathrm{Cr}$-EDTA and for the calculation of urinary flow rate, GFR, fractional sodium reabsorption, and free water clearance. Throughout the 8 -h period a solution of $0.9 \% \mathrm{NaCl}(\mathrm{w} / \mathrm{v})$ containing $0.5 \mu \mathrm{Ci} / \mathrm{ml}{ }^{51} \mathrm{Cr}$-EDTA and $52.29 \pm 1.08(n=20)$ $\mathrm{mmol} /$ liter lithium was infused at $1.9 \mathrm{ml} / \mathrm{h}$ using a Braun Perfusor VI pump. Fractional lithium reabsorption was used as an index of fractional sodium reabsorption in the proximal tubule.

The 8-h experimental protocol consisted of a 1-h equilibration period, a 1 -h control period, a 4-h infusion period where either cortisol (Steraloids Inc. Wilton, $\mathrm{NH}$ ) $100 \mu \mathrm{g} / \mathrm{h}$ or $0.9 \% \mathrm{NaCl}(\mathrm{w} /$ v) was infused followed by a $2 \mathrm{~h}$ postinfusion period.

Fetal arterial blood samples $(2.2 \mathrm{ml})$ were collected half-way through each urine collection period, for the measurement of $\mathrm{pH}$, osmolality, electrolyte concentrations, ${ }^{51} \mathrm{Cr}$-EDTA, and for the calculation of GFR, fractional sodium reabsorption, and free water clearance. Samples of fetal arterial blood $(10 \mathrm{ml})$ and maternal venous blood $(20 \mathrm{ml})$ were collected at the end of the infusion period for the assay of aldosterone, corticosterone and cortisol. Aliquots of the infusate were taken for the assay of cortisol.

Sample analysis. Osmolality was measured by freezing point depression using an Advanced Instruments Osmometer. Sodium and potassium concentrations in plasma and urine were measured on a Beckman system E2A electrolyte analyzer (Beckman Instruments Inc., Fullerton, CA); urinary chloride was measured using Standard Technicon Autoanalyser techniques. Urine ionized Ca concentrations were measured by a Radiometer ICA1 ionized calcium analyzer (Radiometer America Inc., Westlake, $\mathrm{OH})$. Fetal arterial blood $\mathrm{pH}, \mathrm{PCO}_{2}$ and $\mathrm{PO}_{2}$ were all measured on a Corning 108 blood gas machine (Corning Glass Works, Corning, NY). Lithium was measured in plasma and urine using a Varian Spectra AA-40 atomic absorption spectrophotometer (Varian Associates, Inc., Palo Alto, CA). This procedure has been described previously by Shine et al. (17).

Steroids were measured by the double isotope dilution derivative assay which has been validated for use in ovine fetal blood (18).

Formulae. GFR was calculated from the standard formula:

$$
\frac{\mathrm{U} . \mathrm{V}}{\mathrm{P}} \text { for }{ }^{51} \mathrm{Cr}-\mathrm{EDTA}
$$

where $\mathrm{U}$ is urine concentration; $\mathrm{V}$ is urine flow rate; and $\mathrm{P}$ is plasma concentration.

Free water clearance was calculated from the formula:

$$
\mathrm{C}_{\mathrm{H}_{2} \mathrm{O}}=\mathrm{V}-\frac{\text { Uosmol. V }}{\text { Posmol }}
$$

Fractional $\mathrm{Na}$ and $\mathrm{Li}$ reabsorption rates were calculated by the formulas:

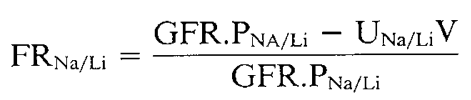

Distal tubular sodium reabsorption was calculated from the total minus the calculated proximal tubular reabsorption.

Statistics. Values are mean \pm SEM. The significance of the difference between plasma aldosterone, corticosterone, and cortisol concentrations during cortisol or isotonic saline infusions were tested using the Student's $t$-test for independent means. The Student's $t$-test was also used to assess the significance of difference in urinary parameters between mature and immature fetuses. For changes in urinary parameters with time, in either mature or immature fetuses, a two-way ANOVA was used. Linear regression was calculated using the least squares method and the significance of the regression was estimated by calculating an analysis of variance about that regression.

\section{RESULTS}

Immature fetuses had a mean age of $113.9 \pm 1.4(n=10)$ days, whereas mature fetuses were $133.4 \pm 1.7(n=10)$ days of gestation on the day of experimentation. The values for fetal arterial blood $\mathrm{pH}, \mathrm{PCO}_{2}, \mathrm{PO}_{2}$, and urine osmolality at the commencement of experiments in immature fetuses were $7.36 \pm$ $0.01,47.4 \pm 1.3(\mathrm{~mm} \mathrm{Hg}), 22.7 \pm 1.2(\mathrm{~mm} \mathrm{Hg})$, and $143.5 \pm$ $8.1 \mathrm{mosmol} / \mathrm{kg}$ water although in mature fetuses they were 7.34 $\pm 0.04,47.7 \pm 1.5(\mathrm{~mm} \mathrm{Hg}), 24.6 \pm 0.9(\mathrm{~mm} \mathrm{Hg})$, and $101.5 \pm$ $6.8 \mathrm{mosmol} / \mathrm{kg}$ water. These are well within the range for unstressed fetuses with low plasma ACTH concentrations in our laboratory (16).

Analysis of cortisol infusates showed that immature fetuses received $81.5 \pm 15.4(n=5) \mu \mathrm{g} / \mathrm{h}$ whereas mature fetuses received $107.2 \pm 4.7(n=5) \mu \mathrm{g} / \mathrm{h}$. Corticosterone and cortisol at the end of the infusion of saline/cortisol are shown in Table 1.

Cortisol infused at $81.5 \pm 15.4(n=5) \mu \mathrm{g} / \mathrm{h}$ into immature fetuses significantly increased urinary excretion of $\mathrm{Na}, \mathrm{K}, \mathrm{Cl}$, and $\mathrm{Ca}$ from $0.45 \pm 0.03,0.11 \pm 0.04,0.23 \pm 0.24 \mathrm{mmol} / \mathrm{h}$ and $0.006 \pm 0.017 \mathrm{mmol} / \mathrm{h}$ to $1.80 \pm 0.42(p<0.001), 0.24 \pm 0.06$ $(p<0.002), 1.38 \pm 0.39(p<0.001)$, and $0.0295 \pm 0.0081(p$ $<0.006) \mathrm{mmol} / \mathrm{h}$, respectively, in the 4 th $\mathrm{h}$ of the infusion period. Saline infused into the same animals produced no significant changes in urinary $\mathrm{Na}, \mathrm{K}, \mathrm{Cl}$, and $\mathrm{Ca}$ excretion, which were $0.75 \pm 0.22,0.15 \pm 0.03,0.46 \pm 0.20$, and $0.0059 \pm 0.0013$ $\mathrm{mmol} / \mathrm{h}$ before the saline infusion and $0.71 \pm 0.15,0.15 \pm 0.04$, $0.49 \pm 0.13$, and $0.0074 \pm 0.0022 \mathrm{mmol} / \mathrm{h}$ at the end of the $4 \mathrm{th}$ $\mathrm{h}$ of the saline infusion. $\mathrm{C}_{\mathrm{H}_{2} \mathrm{O}}$ in immature fetuses also significantly $(p<0.009)$ increased from $10.8 \pm 1.8$ to $17.4 \pm 1.2 \mathrm{ml} /$ $\mathrm{h}$ during the 4 -h cortisol infusion. This was solely due to significant $(p<0.001)$ increases in urine flow, which increased from $17.6 \pm 1.7$ to $35.8 \pm 4.4 \mathrm{ml} / \mathrm{h}$, as no significant change in urine osmolality occurred (from $119.8 \pm 10.4$ to $146.8 \pm 11.6 \mathrm{mosmol}$ / $\mathrm{kg}$ during the $4 \mathrm{~h}$ cortisol infusion) (See Fig. 1).

Cortisol infused at 107.2 $\pm 4.7(n=5) \mu \mathrm{g} / \mathrm{h}$ into mature fetuses had no significant effect on urinary excretion of $\mathrm{Na}, \mathrm{K}, \mathrm{Cl}$ and $\mathrm{Ca}, \mathrm{C}_{\mathrm{H}_{2} \mathrm{O}}$, urine flow, and osmolality which during the control period were found to be $0.83 \pm 0.35,0.20 \pm 0.04,0.22 \pm 0.06$, and $0.0044 \pm 0.0011 \mathrm{mmol} / \mathrm{h}, 20.4 \pm 0.5 \mathrm{ml} / \mathrm{h}, 31.2 \pm 8.9 \mathrm{ml} /$

Table 1. Concentrations of corticosterone and cortisol in maternal and fetal blood at end of infusion period of isotonic saline $(0.9 \% \mathrm{NaCl})$ or cortisol $(100 \mu \mathrm{g} / \mathrm{h})$ into ovine fetus [mean $\pm S E M$, (no. of samples)]

\begin{tabular}{ccc}
\hline & $\begin{array}{c}\text { Corticosterone } \\
\text { (nmol/liter) }\end{array}$ & $\begin{array}{c}\text { Cortisol } \\
\text { (nmol/liter) }\end{array}$ \\
\hline Isotonic saline & & \\
$\quad$ Maternal & $1.2 \pm 0.2(9)$ & $12.2 \pm 2.1(9)$ \\
Fetal <120d & $0.9 \pm 0.2(5)$ & $0.8 \pm 0.5(4)$ \\
$>120 \mathrm{~d}$ & $1.7 \pm 0.6(5)$ & $11.4 \pm 5.6(5)$ \\
Cortisol & & \\
$\quad$ Maternal & $1.6 \pm 0.3(10)$ & $14.1 \pm 2.9(10)$ \\
Fetal <120d & $1.2 \pm 1.7(5)$ & $21.3 \pm 6.2(5)$ \\
$>120 \mathrm{~d}$ & $1.8 \pm 1.0(5)$ & $33.7 \pm 6.8(5)$ \\
\hline
\end{tabular}


$\mathrm{h}$ and $98.4 \pm 6.0 \mathrm{mosmol} / \mathrm{kg}$, respectively, whereas at the end of the 4-h infusion period were $1.04 \pm 0.31,0.30 \pm 0.08,0.38 \pm$ 0.08 and $0.0057 \pm 0.0010 \mathrm{mmol} / \mathrm{h}, 31.8 \pm 0.8 \mathrm{ml} / \mathrm{h}, 46.44 \pm$ $11.7 \mathrm{ml} / \mathrm{h}$, and $104.6 \pm 15.9 \mathrm{mosmol} / \mathrm{kg}$. Saline infused for $4 \overline{\mathrm{h}}$ into mature fetuses similarly had no effect on the above urinary parameters (see Fig. 2).

Using the Student's $t$-test for independent means, no significant difference was found in urinary excretion of $\mathrm{Na}, \mathrm{K}, \mathrm{Cl}$, and $\mathrm{Ca}$ during the control periods, between immature and mature fetuses. Urine flow $(p<0.005), \mathrm{C}_{\mathrm{H}_{2} \mathrm{O}}(p<0.005)$, and GFR $(p$ $<0.001)$ during control periods were significantly greater in mature fetuses when compared to immature fetuses, while urine osmolality was significantly greater $(p<0.001)$ in immature fetuses.

No significant difference in either fractional sodium or fractional lithium reabsorption were found between mature and immature fetuses during the control periods (Figs. 1 and 2). Cortisol caused a significant depression of proximal tubular sodium reabsorption in both immature and mature fetuses. There was an increase in distal tubular sodium reabsorption in

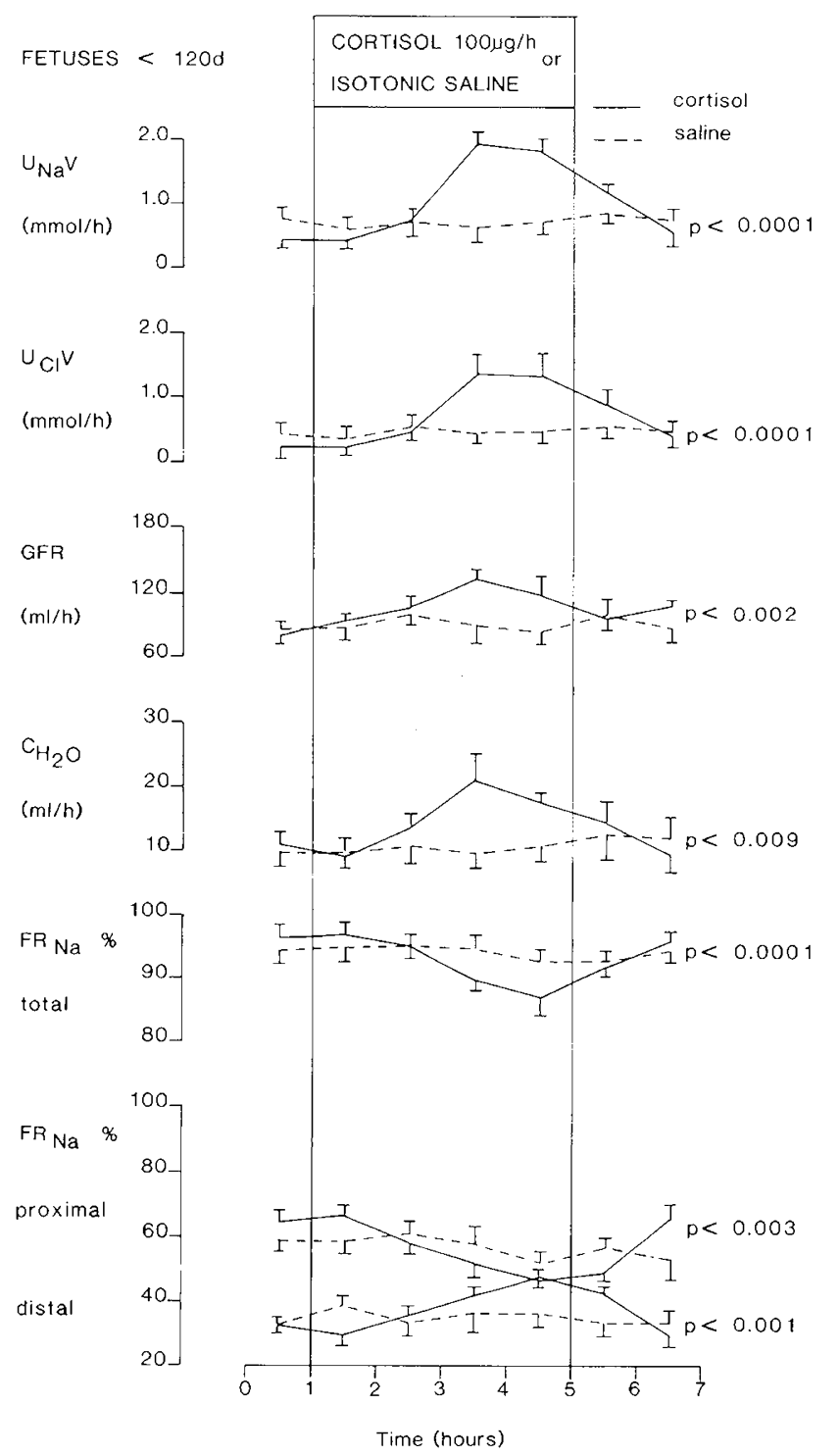

Fig. 1. $\mathrm{U}_{\mathrm{Na}} \mathrm{V}, \mathrm{U}_{\mathrm{Cl}} \mathrm{V}, \mathrm{GFR}$, free water clearance $\left(C_{\mathrm{H}_{2} O} \mathrm{O}\right), \mathrm{FR}_{\mathrm{Na}}$, and proximal and distal $F R_{\mathrm{Na}}$ in immature ovine fetuses $(<120$ days of gestation). Proximal reabsorption was calculated from lithium clearance. ---, Saline infusion. —- Cortisol infusion $(100 \mu \mathrm{g} / \mathrm{h})$. Values are mean \pm SEM. Two-way ANOVA indicates significant effects of cortisol infusion at levels indicated in each panel.

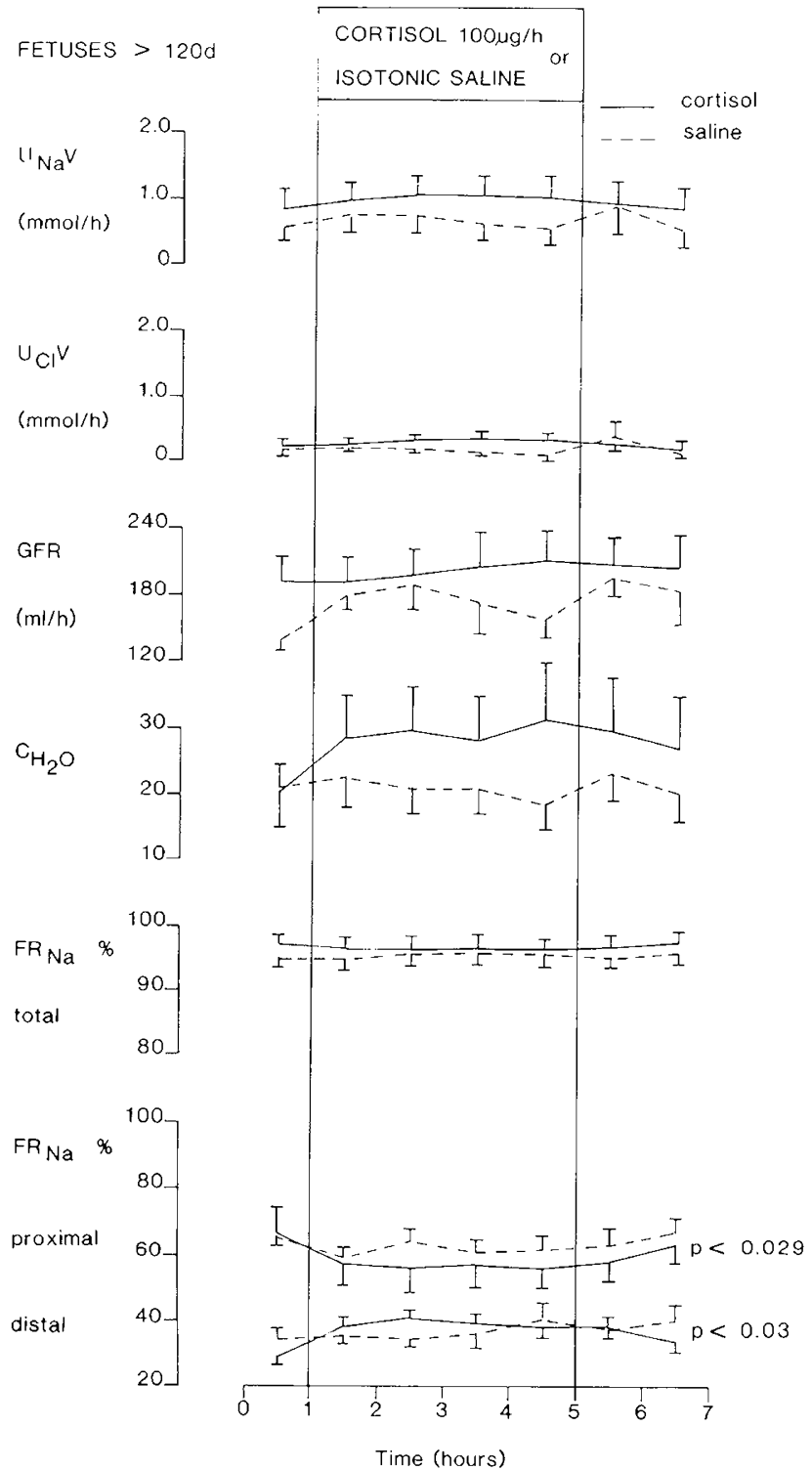

Fig. 2. $U_{\mathrm{Na}} \mathrm{V}, \mathrm{U}_{\mathrm{Cl}} \mathrm{V}, \mathrm{GFR}, \mathrm{FR}_{\mathrm{Na}}$, and total, proximal, and distal $\mathrm{FR}_{\mathrm{Na}}$ in mature ovine fetuses ( $>120$ days of gestation). Proximal reabsorption was calculated from lithium clearance. ---, Saline infusion. - Cortisol infusion $(100 \mu \mathrm{g} / \mathrm{h})$. Values are mean \pm SEM. Two-way ANOVA indicates significant effects of cortisol infusion in bottom panel.

both groups of fetuses, but it was sufficient to overcome the increased delivered load in the mature fetuses only.

GFR was significantly increased $(p<0.002)$ by the $3 \mathrm{rd} \mathrm{h}$ of the cortisol infusion in immature fetuses (Fig. 1). No similar effect was shown in mature fetuses (Fig. 2). Both fractional sodium $(p<0.001)$ and fractional lithium $(p<0.003)$ reabsorptions were significantly reduced by the $3 \mathrm{rd} h$ of the cortisol infusion in immature fetuses (see Fig. 1). Fractional lithium reabsorption was also significantly reduced $(p<0.029)$ in mature fetuses. Saline infusions into both mature and immature fetuses had no significant effect on either fractional sodium or fractional lithium reabsorptions (see Figs. 1 and 2). No significant correlation $(r=0.33, p<0.61)$ could be found between blood cortisol concentrations and urinary sodium excretion, with combined data from both mature and immature fetuses.

In Figures 3 and 4 the amount of sodium reabsorbed in proximal and distal segments of the nephron are plotted against GFR for the immature and mature fetuses. There was a highly significant correlation between GFR and amount of sodium reabsorbed in both proximal and distal segments. The gradient 


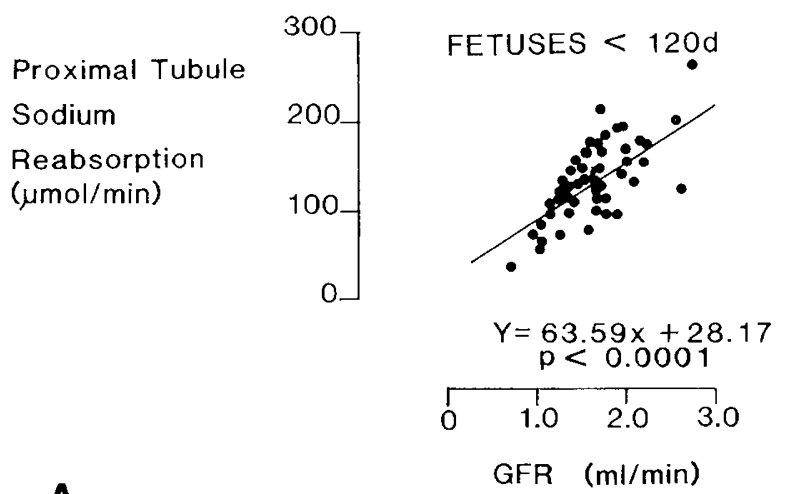

A

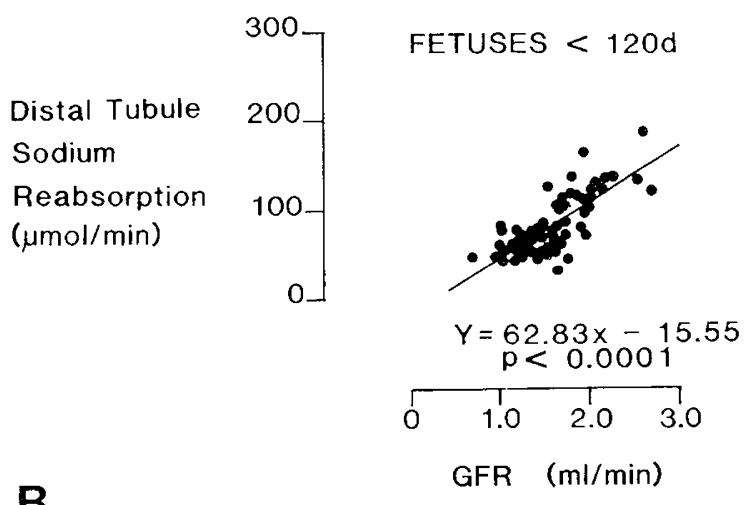

Fig. 3. Sodium reabsorption in proximal $(A)$ and distal $(B)$ segments of the nephron in relation to GFR in immature ovine fetuses $(<120$ days of gestation). Proximal reabsorption was calculated from lithium clearance.

of the line for the distal tubule was greater in the more mature fetuses $(p<0.01)$, indicating that distal mechanisms are more mature in the older fetuses.

\section{DISCUSSION}

The infusion of cortisol at the rates of $81.52 \pm 15.4$ (5) and $107.2 \pm 4.7$ (4) $\mu \mathrm{g} / \mathrm{h}$ into immature and mature fetuses, respectively, produced blood concentrations of $21.32 \pm 6.23$ (5) and $33.72 \pm 6.81$ (5) nmol/liter, respectively. Blood clearance rates of cortisol were found to be $13.56 \pm 3.92(5) \mathrm{L} / \mathrm{h}(<120$ days of gestation) and $11.60 \pm 2.04(5) \mathrm{L} / \mathrm{h}(>120$ days of gestation). These were well within the range of values previously reported in this laboratory (19).

Although higher blood cortisol concentrations were achieved in mature fetuses, exogenous cortisol had no significant effect on urinary sodium, potassium, chloride and calcium excretion, or free water clearance, whereas the lower blood cortisol concentrations achieved in the immature fetuses significantly increased each of these urinary parameters. These results suggest that an ontogenetic change, in fetal renal responsiveness to cortisol, occurs late in the last third of gestation.

The mechanism(s) by which cortisol exerts its renal effects has yet to be elucidated. Numerous studies have reported the presence of glucocorticoid receptors in renal glomeruli $(20,21)$, but precisely how glucocorticoids influence renal function is not clearly understood, even in the adult. It has been reported that glucocorticoid binding sites, as measured with $\left[{ }^{3} \mathrm{H}\right]$ triamcinolone-acetonide, decrease in rat kidneys with increasing post-natal age, from $20-40$ days (22). The rat kidney is relatively immature at birth, nephrogenesis not being complete until after birth (23). Nephrogenesis is complete before birth in ovine fetuses (24). Thus glucocorticoid receptors might decrease or be down-regu-
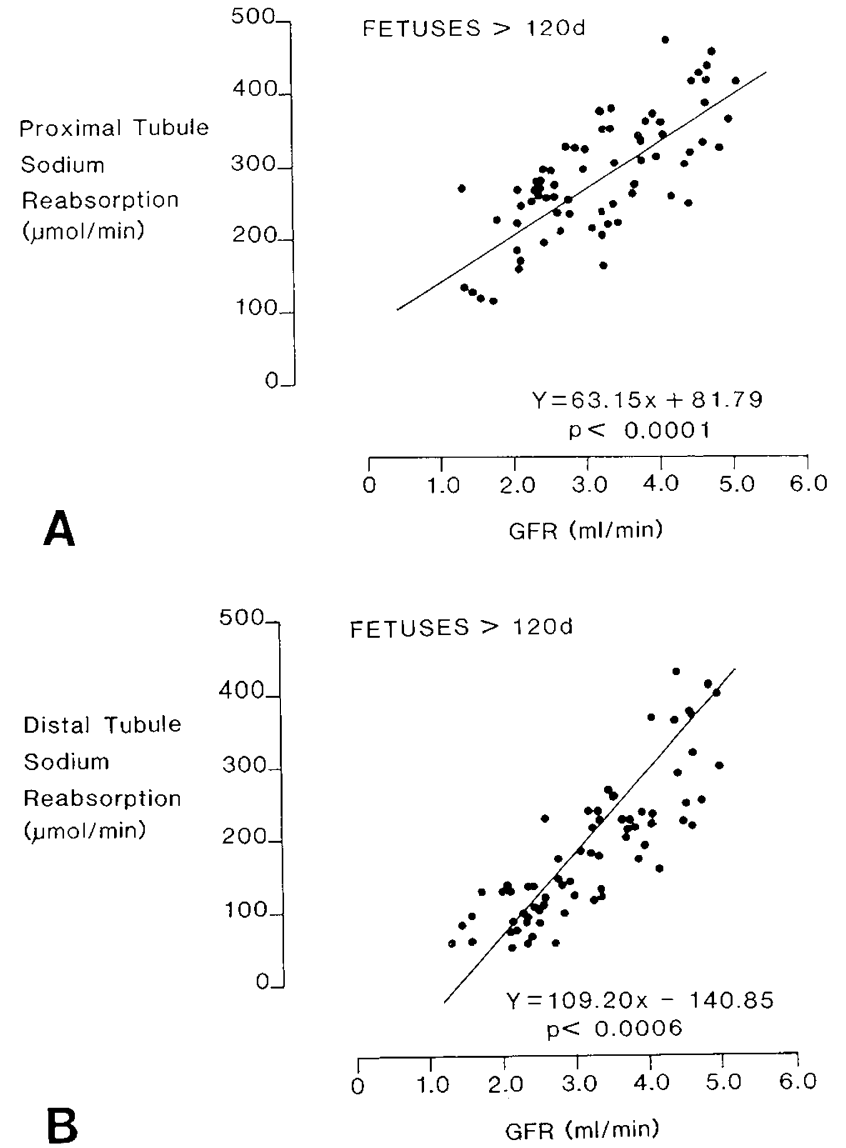

Fig. 4. Sodium reabsorption in proximal $(A)$ and distal $(B)$ segments of the nephron in relation to GFR in mature ovine fetuses $(>120$ days of gestation). Proximal reabsorption was calculated from lithium clearance.

lated before birth in ovine kidneys, although there have not yet been studies in this area. This could account for the absence of change in GFR in the mature fetuses.

The acute effects of a 4-h infusion of cortisol on fetal renal function must be differentiated from the effects of a longer exposure to increased glucocorticoids late in gestation. It is well known that maturational changes occur in fetal renal function as term approaches. In both acute and chronic preparations it has been shown that GFR in the ovine fetus increases absolutely with increasing gestational age, but remains constant when expressed as $\mathrm{ml} / \mathrm{min} / \mathrm{g}$ of kidney wt (24-27). At birth there is a disproportionate increase in GFR (25). Stonestreet et al. (28) found that fetal lambs prematurely delivered, due to intramuscular injections of bethamethasone, had higher GFR and lower fractional sodium excretion than did placebo treated fetuses near term, or full-term lambs, suggesting that glucocorticoids may be involved in functional maturation of the kidney.

Significant increases in urinary sodium excretion were also accompanied by a significant decrease in fractional lithium reabsorption in immature fetuses. Lithium reabsorption correlates well in some adult kidneys with sodium reabsorption in the proximal convoluted tubule (29-31). It has been shown recently that lithium reabsorption is also a good index of proximal tubular sodium reabsorption in the ovine fetus (31) (Lumbers ER, personal communication).

The clearance of lithium represents the clearance from the proximal convoluted tubule and the pars recta, and the distal tubular reabsorption of sodium calculated in this report represents all the sodium reabsorbed from this point to the end of the nephron.

Thus it seems that at least some of the effect of cortisol in 
immature fetuses was due to the proximal tubule rejection of sodium. Parallel decreases in $\mathrm{FR}_{\mathrm{Na}}$ in the present study also support this. In mature fetuses significant decreases in $\mathrm{FR}_{\mathrm{Li}}$ were not accompanied by changes in fractional sodium reabsorption, suggesting that more distal tubule sodium reabsorption was occurring in these older fetuses. The absence of an increase in GFR, with cortisol infusion, in the mature fetuses, in addition to a more effective distal tubular sodium reabsorption, may be responsible for the absence of a natriuretic response in the mature animal. The decrease in urine osmolality that occurs as fetuses mature also argues that distal mechanisms are more effective in $\mathrm{NaCl}$ reabsorption before term (32).

Recently it has been demonstrated (17) in this laboratory that infusions of ANF $(4.4 \mu \mathrm{g} / \mathrm{h})$ into relatively immature ovine fetuses reduce $\mathrm{FR}_{\mathrm{Na}}$ and $\mathrm{FR}_{\mathrm{Li}}$ from $96.5 \pm 1.0$ and $64.3 \pm 7.5 \%$ to $86.5 \pm 2.8$ and $46.8 \pm 9.6 \%$. In the present study similar reductions in $\mathrm{FR}_{\mathrm{Na}}$ and $\mathrm{FR}_{\mathrm{Li}}$ were seen from $96.6 \pm 0.2$ and 65.7 $\pm 2.2 \%$ to $87.35 \pm 3.0$ and $47.0 \pm 7.4 \%$. Analysis of these data using Student's $t$-test for independent means showed that both ANF $(4.4 \mu \mathrm{g} / \mathrm{h})$ and cortisol $(100 \mu \mathrm{g} / \mathrm{h})$ reduced $\mathrm{FR}_{\mathrm{Na}}$ and $\mathrm{FR}_{\mathrm{Li}}$ to the same extent, i.e. there is no significant difference between the effect of cortisol on $\mathrm{FR}_{\mathrm{Na}}$ and $\mathrm{FR}_{\mathrm{Li}}$ when compared to that of ANF. This, however, does not prove that the effects of cortisol are mediated via ANF. In fact the increased sodium excretion seen when ANF was infused occurred in the absence of any change in cortisol values and more recent studies have shown that cortisol does not increase plasma ANF concentrations in the immature ovine fetus (Wintour EM, unpublished data). It is most likely that factors that disrupt glomerular-tubular balance may work on different receptors and mechanisms to achieve the same result.

In conclusion, it has been found that cortisol, in physiologic concentrations, is diuretic and natriuretic in the immature ovine fetus. This effect is not seen in the mature ovine fetus as mechanisms of sodium reabsorption in the nephron distal to the pars recta become increasingly capable of reabsorbing an increased delivery of filtrate. The effects of cortisol and ANF in the immature kidney may explain the inability of premature or low birth wt human neonates to conserve sodium on a standard salt intake (1-3).

\section{REFERENCES}

1. Al-Dahhan J, Haycock GB, Chantler C, Stimmler L 1983 Sodium homeostasis in term and preterm neonates. Arch Dis Child 58:335-342

2. Rodriguez-Soriano J, Vallo A, Oliveros R, Castillo, G 1983 Renal handling of sodium in premature and full-term neonates: a study using clearance methods during water diuresis. Pediatr Res 17:1013-1016

3. Roy RN, Chance GW, Radde IC, Hill DE, Willis DM, Sheepers J 1976 Late hyponatremia in very low birthweight infants $(<1.3$ kilograms). Pediatr Res $10: 526-531$

4. Sulyok E. Nemeth M, Tenyi I, Csaba I, Gyory E, Ertl T, Varga F 1979 Postnatal development of renin-angiotensin-aldosterone system, RAAS, in relation to electrolyte balance in premature infants. Pediatr Res 13:817-820

5. Aperia A, Broberger O Herin, P and Zetterstrom R 1979 Sodium excretion in relation to sodium intake and aldosterone excretion in newborn pre-term and full-term infants. Acta Pediatr Scand 68:813-817

6. Aperia A, Broberger O, Thodenius K, Zetterstrom R 1974 Developmental study of the renal response to an oral salt load in preterm infants. Acta Paediatr Scand 63:517-524
7. MacDonald MS, Emery JL 1959 The late intrauterine and postnatal development of human renal glomeruli. J Anat 93:331-340

8. Fetterman GH, Shyplock NA, Philipp F, Gregg HS 1965 The growth and maturation of human glomeruli and proximal convolutions from term to adulthood. Pediatrics 35:601-606

9. Kleeman CR, Maxwell MH, Rockney RE 1958 Mechanism of impaired water excretion in adrenal and pituitary insufficiency. 1. The role of altered glomerular filtration rate and solute excretion. J Clin Invest 37:1799-1808

10. Kleeman CR, Levi J, Better O 1975 Kidney and adrenocortical hormones. Nephron 15:261-278

11. Garrod O, Davie SA, Cahill G Jr 1955 The action of cortisone and desoxycorticosterone acetate on glomerular filtration rate and sodium and water exchange in the adrenalectomized dog. J Clin Invest 34:761-776

12. Noguchi A, Reynolds JW 1978 Serum cortisol and dehydroepiandrosterone sulfate responses to adrenocorticotropin stimulation in premature infants. Pediatr Res 12:1057-1061

13. Ballard PL, Gluckman PD, Liggins GC, Kaplan SL, Grumbach MM 1980 Steroid and growth hormone levels in premature infants after prenatal betamethasone therapy to prevent respiratory distress syndrome. Pediatr Res 14:122-127

14. Wintour EM, Coghlan JP, Towstoless M 1985 Cortisol is natriuretic in the immature ovine fetus. J Endocrinol 106:R13-R15

15. Lingwood B, Hardy KJ, Horacek I, McPhee ML, Scoggins BA, Wintour EM 1978 The effects of antidiuretic hormone on urine flow and composition in the chronically cannulated ovine fetus. Q J Exp Physiol 63:315-354

16. Wintour EM, Bell RJ, Congiu M, MacIsaac RJ, Wang X 1985 The value of urine osmolality as an index of stress in the ovine fetus. J Dev Physiol 7:347354

17. Shine $P$, McDougall JG, Towstoless MK, Witnour EM 1987 Action of atrial natriuretic peptide in the immature ovine kidney. Pediatr Res 22:11-15

18. Brown EH, Coghlan JP, Hardy KJ, Wintour EM 1978 Aldosterone, corticosterone, cortisol, 11 -deoxycortisol and 11-deoxycorticosterone concentrations in the blood of chronically cannulated ovine foetuses: effect of ACTH. Acta Endocrinol 88:364-374

19. Hennessy DP, Coghlan JP, Hardy KJ, Scoggins BA, Wintour EM 1982 The origin of cortisol in the blood of fetal sheep. J Endocrinol 95:71-79

20. Farman N, Vandewalle A, Bonvalet JP 1982 Autoradiographic study of aldosterone and dexamethasone binding in isolated glomeruli of rabbit kidney. Am J Physiol 243:F235-F242

21. Pertschuk LP, Carvounis EE, Jobin EH, Gaetjens E 1980 Renal glomerular steroid hormone binding. Detection by fluorescent microscopy. J Steroid Biochem 13:1115-1120

22. Aperia A, Haldosen L, Larsson L, Gustafsson S 1985 Ontogeny of triamcinolone-acetonide binding sites in outer cortical tissue from rat kidneys. Am J Physiol 249:F891-F897

23. Spitzer A 1985 The Kidney: Physiology and Pathophysiology. Raven Press, New York, pp 1979-2015

24. Robillard JE, Weismann DN, Herin P 1981 Ontogeny of single glomerular filtration rate in fetal and newborn lambs. Pediatr Res 15:1248-1255

25. Robillard JE, Kulvinskas C, Sessions C, Burmeister L, Smith FG Jr 1975 Maturational changes in the fetal glomerular filtration rate. Am J Obstet Gynecol 122:601-607

26. Robillard JE, Sessions C, Kennedey RL, Hamel-Robillard L, Smith FG Jr 1977 Interrelationship between glomerular filtration rate and renal transport of sodium and chloride during fetal life. Am J Obstet Gynecol 128:727-734

27. Robillard JE, Weitzman RE, Burmeister L, Smith FG Jr 1981 Developmental aspects of the renal response to hypoxemia in the lamb fetus. Circ Res 48:128-138

28. Stonestreet BS, Hansen NB, Laptook AR, Oh W 1983 Glucocorticoid accelerates renal functional maturation in fetal lambs. Early Hum Dev 8:331341

29. Hayslett JP, Kashgarian M 1979 A micropuncture study of the renal handling of lithium. Pflugers Arch 380:159-163

30. Thomsen K, Shou M 1986 Lithium clearance: a new research area. News Physiol Sci 1:126-128

31. Lumbers ER, Hill KJ, Bennett VJ 1988 Proximal and distal tubular activity in the chronically catheterized fetal sheep compared with the adult. Can $\mathbf{J}$ Physiol Pharmacol 66:697-702

32. Wintour EM, Congiu M, Hardy KJ, Hennessy DP 1982 Regulation of urine osmolality in fetal sheep. Q J Exp Physiol 67:427-435 